\title{
GRATIFIKASI DAN PELAYANAN SIPIL : SUATU FENOMENA SOSIAL DALAM KEHIDUPAN MASYARAKAT
}

\author{
'Yadi Ruyadi dan ${ }^{2}$ Encep Syarif, ${ }^{3}$ Irwan Sofyan \\ 1Dosen Prodi Pendidikan Sosiologi FPIPS Universitas Pendidikan Indonesia \\ 2Dosen Prodi Pendidikan Sosiologi FPIPS Universitas Pendidikan Indonesia \\ 3Universitas Pendidikan Indonesia \\ E-mail: yadiruyadi016@upi.edu
}

\begin{abstract}
ABSTRAK
Pada dasarnya masyarakat sangat mengecam tindakan korupsi, akan tetapi dalam kehidupan sehari-hari masyarakat seolah membenarkan perilaku korupsi. Gratifikasi merupakan sebuah kebiasaan yang sering ditemukan dalam masyarakat Cianjur. Tujuan dari diadakannya penelitian ini adalah untuk mengetahui bagaimana pemahaman, persepsi serta adakah pengaruh budaya masyarakat terhadap perilaku gratifikasi pada pelayanan sipil. Penelitian ini menggunakan pendekatan kualitatif dan metode deskriptif. Teknik pengumpulan data dilakukan melalui wawancara, observasi, studi dokumentasi. Penelitian mengungkapkan bahwa dilihat dari nilai dan norma sosial memberikan uang ucapan terima kasih merupakan sesuatu yang dianggap baik dan patut dilakukan. Masyarakat memersepsikan bahwa dengan memberikan uang ucapan terima kasih pelayanan dirasakan lebih cepat dan baik dibandingkan dengan tidak memberikan. Adanya kebiasaan memberikan uang ucapan terima kasih ini merupakan sebuah perilaku yang membudaya di masyarakat Cianjur, perilaku tersebut secara terus menerus tersosialisasikan dalam masyarakat sehingga membentuk pola assosiasi diferensial.

Kata Kunci: Persepsi, Gratifikasi, Pelayanan Sipil
\end{abstract}

\section{PENDAHULUAN}

Masyarakat

merupakan

kumpulan manusia yang hidup bersama di dalam sebuah sistem sosial budaya yang di kembangkan oleh masyarakat itu sendiri, Koentjaraningrat (2009, hlm 118) menyebutkan bahwa "Masyarakat adalah kesatuan hidup manusia yang berinteraksi menurut suatu sistem adat-istiadat tertentu yang bersifat kontinu, dan yang terikat oleh suatu rasa identitas bersama". Hal tersebut menjelaskan bahwa setiap individu dalam masyarakat berinteraksi sesuai dengan adat-istiadat tertentu yang dilakukan secara terus menerus yang menjadikannya sebuah pola perilaku yang berada di dalam masyarakat itu sendiri. Dalam penelitian ini sebuah kebiasaan gratifikasi yang ada di dalam masyarakat Cianjur sudah merupakan sebuah hal yang secara budaya itu merupakan sebuah bentuk dari penghargaan kepada orang lain.

Pada dasarnya masyarakat sangat mengecam tindakan korupsi, tetapi dalam kehidupan sehari-hari masyarakat seolah membenarkan perilaku korupsi. Gratifikasi merupakan sebuah kebiasaan yang sering ditemukan di masyarakat Cianjur. dalam penelitian ini memberikan uang ucapan terima kasih pada pelayanan sipil dapat dikategorikan sebagai gratifikasi 
sebagaimana yang diungkapkan oleh KPK bahwa Gratifikasi itu sendiri bisa dikatakan sebagai suap pasif sebagaimana dijelaskan dalam rumusan UU Nomor 20 Tahun 2001 tentang perubahan UU nomor 31 tahun 1999 tentang pemberantasan tindak pidana korupsi. Seperti yang diungkapkan dalam kutipan pada Tabel 2.1 tentang pertanyaan masalah gratifikasi; "Seorang penyelenggara negara/pegawai negeri yang bertugas memberikan layanan publik pembuatan KTP, menerima pemberian dari pengguna layanan sebagai tanda terima kasih atas pelayanan yang dinilai baik. Pengguna layanan memberikan uang kepada petugas tersebut secara sukarela dan tulus hati".

\section{Tabel 2.1 Pertanyaan Masalah Gratifikasi}

\begin{tabular}{|c|}
\hline $\begin{array}{l}\text { Pertanyaan: } \\
\text { Apakah pemberian hadiah/uang } \\
\text { sebagai ucapan terima kasih atas } \\
\text { asa yang diberikan oleh instansi } \\
\text { Jelayanan sipil termasuk konsep } \\
\text { gratifikasi yang dilarang? }\end{array}$ \\
\hline \\
\hline $\begin{array}{l}\text { Pertanyaan: } \\
\text { Mengapa permasalahan di atas } \\
\text { ermasuk konsep gratifikasi yang } \\
\text { dilarang? }\end{array}$ \\
\hline $\begin{array}{l}\text { Jawaban: } \\
\text { Walaupun pemberian tersebut } \\
\text { diberikan secara sukarela dan tulus } \\
\text { hati kepada petugas layanan, tetapi } \\
\text { pemberian tersebut dapat } \\
\text { dikategorikan sebagai pemberian } \\
\text { yang berhubungan dengan jabatan } \\
\text { dan berkaitan dengan kewajiban } \\
\text { penyelenggara negara/pegawai } \\
\text { negeri, karena pelayanan yang baik } \\
\text { memang harus diberikan oleh }\end{array}$ \\
\hline
\end{tabular}

petugas sebagai bentuk
pelaksanaan tugasnya. Oleh karena itu, masyarakat berhak dan pantas untuk mendapatkan layanan yang baik.

\section{Pertanyaan:}

Apa tindakan yang seharusnya petugas lakukan dalam kondisi ini?

\section{Jawaban:}

Sebaiknya petugas menSebaiknya petugas menolak pemberian dan menjelaskan kepada pengguna layanan bahwa apa yang dilakukannya adalah bagian dari tugas dan kewajiban petugas tersebut.

Untuk pengguna layanan sebaiknya tidak memberikan uang/benda apapun sebagai tanda terima kasih atas pelayanan yang dia dapat, karena pelayanan yang diterima tersebut sudah selayaknya diterima. Kebiasaan memberi hadiah/uang sebagai wujud tanda terima kasih kepada petugas, akan memicu lahirnya budaya "mensyaratkan" adanya pemberian dalam setiap pelayanan publikolak pemberian dan menjelaskan kepada pengguna layanan bahwa apa yang dilakukannya adalah bagian dari tugas dan kewajiban petugas tersebut.

Untuk pengguna layanan sebaiknya tidak memberikan uang/benda apapun sebagai tanda terima kasih atas pelayanan yang dia dapat, karena pelayanan yang diterima tersebut sudah selayaknya diterima. Kebiasaan memberi hadiah/uang sebagai wujud tanda terima kasih kepada petugas, akan memicu lahirnya budaya "mensyaratkan" adanya pemberian dalam setiap pelayanan publik 
Pelayanan Sipil sendiri menurut Ndraha (2003, hlm.46) memberikan definisi sebagai berikut;

Layanan sipil (Civil Service) adalah hak, kebutuhan dasar dan tuntutan setiap orang lepas dari suatu kewajiban. Bayi dalam kandungan wajib dilindungi oleh pemerintah, walaupun sang bayi tidak (belum) dapat dibebani suatu kewajibannya. Tatkala la lahir, pemerintah wajib mengakui kehadirannya melalui pemberian akta kelahiran, tanpa dimintaminta, dan seharusnya tanpa dibayar, oleh yang bersangkutan. Layanan sipil tidak dijualbelikan (diperdagangkan) di pasar, penyediaannya dimonopoli dan merupakan kewajiban pemerintah.

Berdasarkan definisi yang diuraikan oleh Ndraha, secara makro, begitu manusia berada dalam kandungan ibunya, ia telah memiliki hak asasi yang harus dihormati, diakui dan dilindungi, yaitu hak dan naluri untuk hidup di dalam ruang dan waktu. Perlindungan, pemenuhan dan kontrol itu merupakan kebutuhan (human needs) baik secara individu maupun sosial yang harus menjadi prioritas pemerintahan atau negara dalam pemeliharaan, perlindungan dan pemenuhan tuntutan kebutuhan dasar manusia.

Dalam penelitian ini, pelayanan sipil yang di maksud terepresentasikan pada Dinas Kependudukan dan Catatan Sipil Cianjur sebagai lembaga yang memberikan kebutuhan yang mendasar bagi setiap warga negara. Pada dasarnya pelayanan sipil seharusnya pure no price, dalam artian tidak ada pungutan atau membayar lebih dalam pelaksanaannya. Namun pada kenyataannya praktik gratifikasi masih saja dapat di temukan khususnya di Cianjur.

\section{METODE}

Penelitian ini menggunakan pendekatan kualitatif Alasan pertama, dengan pendekatan kualitatif penelitian ini bertujuan memahami pola penyimpangan sosial gratifikasi pada sektor pelayanan sipil di masyarakat kabupaten Cianjur yang terbentuk dalam masyarakat. Yang kedua, pendekatan kualitatif digunakan untuk memahami fenomena sosial mengenai permasalahan budaya gratifikasi di masyarakat kabupaten Cianjur yang biasa terjadi dewasa ini melalui gambaran yang menyeluruh dan pemahaman yang mendalam. Sebagaimana pendapat Sugiyono (2014, hlm. 15) "objek yang alamiah adalah objek yang berkembang apa adanya, tidak dimanipulasi oleh peneliti dan kehadiran peneliti tidak begitu mempengaruhi dinamika objek tersebut.".

Metode penelitian yang digunakan yaitu metode deskrptif dengan teknik purposive sampling. Partisipan/subjek dalam penelitian ini adalah masyarakat yang secara langsung melakukan tindakan prilaku gratifikasi pada pelayanan sipil di kabupaten Cianjur, petugas pelayanan sipil yang ada di kabupaten Cianjur, tokoh masyarakat, lembaga kemasyarakatan ataupun budayawan Cianjur serta pihak-pihak yang terkait lainnya. Mereka dipilih karena di nilai memahami dan mengerti makna dari prilaku gratifikasi yang sering terjadi di kabupaten Cianjur, dan mereka adalah orang yang terlibat 
dalam kegiatan yang di teliti serta mempunyai waktu untuk diteliti.

Penelitian tentang Persepsi Masyarakat Terhadap Gratifikasi pada Sektor Pelayanan Sipil akan dilakukan di daerah kabupaten Cianjur, dengan pertimbangan bahwa kabupaten Cianjur merupakan daerah yang masih kental akan tradisi dalam masyarakatnya, dalam studi pendahuluan yang dilakukan peneliti juga menemukan temuan yang ternyata masih banyak masyarakat yang masih melakukan gratifikasi terhadap pelayanan sipil, dimungkinkan permasalahan ini dikarenakan konstruksi masyarakatnya

\section{HASIL DAN PEMBAHASAN HASIL \\ Pemahaman Masyarakat Mengenai Gratifikasi}

Banyaknya masyarakat tidak mengetahui dengan pasti apa itu gratifikasi, apa bentuknya dan apakah itu merupakan sebuah penyimpangan secara hukum ataupun sosial. Dalam penelitian yang peneliti lakukan, masih banyak masyarakat yang tidak mengetahui gratifikasi itu sendiri sebelum peneliti jelaskan terlebih dahulu gambaran secara umumnya. Hal ini juga berlaku bagi masyarakat juga pegawai dari dinas kependudukan yang ketika hendak di tanyakan apa anda mengetahui arti dari gratifikasi, beliau malah berbalik tanya seolah hendak ingin menguji peneliti dengan pertanyaan "coba anda dulu yang jelaskan". Dengan sikap yang seperti itu sudah jelas bahwa tidak semua pegawai pemerintahan khususnya Dinas Kependudukan dan Catatan Sipil mengetahui secara pasti apa itu gratifikasi, dan potensi apa yang akan di timbulkan dari adanya perilaku gratifikasi tersebut. Masyarakat menganggap bahwa gratifikasi sendiri yang membenarkan dan membiarkan kebiasaan gratifikasi pada kehidupan sehari-hari sehingga terbawa kepada gratifikasi pelayanan sipil, padahal gratifikasi pada pelayanan sipil sendiri sudah melanggar peraturan yang berlaku serta menyalahi kode etik kepegawaian.

Peneliti sebagai human instrument sebagaimana yang di ungkapkan Sugiono (2008, hlm.59) "dalam penelitian kualitatif, yang menjadi instrumen atau alat penelitian adalah peneliti". Serta di dukung oleh teknik pengumpulan data melalui observasi, wawancara serta studi dokumentasi.

merupakan salah satu bagian dari suap, hanya dengan pengistilahan yang berbeda, padahal apabila di kaji lebih dalam jauh lagi gratifikasi berbeda dengan perilaku suap yang sudah jelas itu merugikan negara.

Rendahnya pemahaman masyarakat mengenai gratifikasi ini juga di tandai dengan banyaknya masyarakat yang tidak mengetahuinya peraturan yang berkaitan dengan gratifikasi itu sendiri. Mungkin karena gratifikasi merupakan istilah yang jarang terdengar oleh masyarakat secara umum, di mana masyarakat lebih mengenal dengan istilah uang ucapan terima kasih. Pada dasarnya peraturan yang mengatur mengenai gratifikasi atau dengan kata lain"memberikan uang ucapan terima kasih" bertujuan untuk melindungi masyarakat dari kekuasaan dan jabatan sehingga pungutan-pungutan dalam bentuk apapun baik uang ataupun barang, baik itu ketika di minta ataupun tidak (tetapi tetap diterima) itu tidak memengaruhi sebuah pengambilan keputusan. "Masyarakat berhak untuk mendapatkan pelayanan secara prima tanpa harus adanya gratifikasi, sehingga tidak ada penyalahgunaan kekuasaan 
dan jabatan yang tidak ada hubungannya dengan profesionalisme" pungkas dari salah satu informan Adam Jabar. Salah satu informan yaitu bapak Nana mengungkapkan bahwa "gratifikasi tersebut dapat di sebut gratifikasi yang melanggar hukum apabila di atas satu juta, dan apabila di bawah satu juta itu bukan gratifikasi". Lain halnya dengan bapak Irfan dan bapak Febi yang masih mempertanyakan mengenai peraturan gratifikasi ini apakah masih cukup relevan apabila di tarik kepada semua aspek yang pada khususnya dalam sektor pelayanan sipil itu sendiri. Mereka berpendapat bahwa memberikan uang ucapan terima kasih ini apabila hanya mempunyai niatan yang baik ikhlas dan tidak ada maksud lainnya maka tidak bisa di permasalahkan. Maka dari itu, menurut bapak Irfan dan Febi, bahwa mengenai peraturan gratifikasi ini perlu ada peninjauan dan adanya indikator yang jelas sehingga apakah perilaku gratifikasi pada sektor pelayanan sipil ini di perbolehkan ataukah tidak.

Penemuan yang menarik perhatian peneliti untuk dibahas yaitu saat kebiasaan masyarakat memberikan uang ucapan terima kasih pada pelayanan sipil ini justru dianggap hal yang lumrah oleh masyarakat, berkaitan dengan nilai kebenaran yang ada, masyarakat merasa bahwa memberikan uang ucapan terima kasih ini asalkan tidak bertujuan lain (seperti halnya ingin di percepat prosesnya atau sebagai uang pelicin) dan di berikan dengan tulus dan ikhlas, menurut masyarakat bukanlah sebuah penyimpangan sosial. Apabila di lihat dari sudut pandang agama, memberikan uang ucapan terima kasih menurut masyarakat justru perbuatan yang baik, di mana ini bisa bertujuan untuk menjalin silaturahmi yang baik diantara umat manusia. Selain itu juga ada sebuah pepatah mengatakan bahwa "tangan di atas lebih baik dibanding dengan tangan di bawah" juga "jangan menolak rezeki" menjadi landasan masyarakat dan petugas pelayanan sipil dalam perilaku gratifikasi ini khususnya memberikan uang ucapan terima kasih yang pada pembahasan kali ini di sektor pelayanan sipil.

Berbeda dengan memberikan gratifikasi dalam sudut pandang norma agama, masyarakat seperti sedikit ragu dalam menjawab bahwa itu merupakan hal yang menyimpang ataupun menyalahi hukum. Itu terjadi karena masyarakat sendiri kurang begitu memahami dan mengetahui peraturan mengenai gratifikasi itu sendiri. Sedikitnya keinginan masyarakat untuk mengetahui peraturan gratifikasi ini juga minimnya pemerintah ataupun pihak terkait dalam mengkampanyekan peraturan dan himbauan gratifikasi ini membuat banyak masyarakat masih meragu dalam menjawab pertanyaan apakah memberikan uang ucapan terima kasih ini menyalahi norma hukum atau tidak. Masyarakat beranggapan memberikan uang ucapan terima kasih ini menyalahi hukum apabila ada maksud lain dalam pemberian uang ucapan terima kasih ini, seperti ingin di percepat atau sebagai pelicin agar pembuatan pelayanan sipil lancar, dan atau ketika petugas penyelenggara pelayanan yang menarifkan atau meminta uang tersebut itu barulah sebuah pelanggaran terhadap peraturan hukum yang berlaku. Akan tetapi apabila pemberian itu tidak di maksudkan dengan tujuan lain dan memberikannya hanya dengan tulus ikhlas masyarakat sependapat bahwa itu bukanlah sebuah pelanggaran 
terhadap hukum. Namun salah satu informan mengatakan bahwa;

Hal ini masih menjadi sebuah perdebatan, memang secara norma hukum memberikan uang ucapan terima kasih bisa di kaitkan dengan pelanggaran hukum, tetapi ini masih tumpang tindih dengan kebiasaan masyarakat yang selalu berperilaku seperi itu. Karena secara adat istiadat dan agama itu tidaklah dipermasalahkan tetapi di mata hukum yang normatif itu merupakan sebuah penyimpangan. Jadi maksud saya apabila itu memang pelanggaran norma hukum, gratifikasi yang seperti apa dulu

Pendapat tersebut menegaskan bahwa gratifikasi pada pelayanan sipil khususnya tidak menjadi sebuah permasalahan hukum apabila tidak memiliki tujuan lain yang sifatnya ilegal, akan tetapi gratifikasi tersebut masih selaras dengan nilai dan norma yang berlaku di masyarakat umum khususnya masyarakat Cianjur.

\section{Persepsi Masyarakat Mengenai Perilaku Gratifikasi dalam Pelayanan Sipil (Civil Service)}

Berdasarkan hasil dari penelitian, perilaku gratifikasi pada pelayanan sipil di kabupaten Cianjur merupakan hal yang lumrah, perilaku seperti ini memang sudah ada dari sejak lama dan terus bertahan, tidak hanya pada aspek pelayanan sipil saja, namun di seluruh lembaga yang mengurusi bidang administrasi maupun non-lembaga, dan dalam kehidupan sehari-hari.

Perilaku gratifikasi yang terjadi di masyarakat yaitu berupa uang ucapan terima kasih terhitung masih di lakukan sampai sekarang, walaupun banyak pamflet ataupun baner yang mengatakan bawa untuk setiap pelayanan sipil tidak di pungut biaya sepeserpun, akan tetapi dalam hal ini masyarakat sendiri yang secara inisiatif memberikan uang tersebut kepada petugas pelayanan. Dalam observasi yang peneliti lakukan, memang dari petugas pelayanan sipil sendiri tidak ada satupun yang meminta ataupun menarifkan jasa pelayanannya. Pelayanan dari Dinas Kependudukan dan Catatan Sipil sudah baik dan mengikuti prosedur yang sudah ada, jenis pelayanannya pun bisa bersifat formal untuk sebagian masyarakat, dan beberapa masyarakat yang kurang lebih sering berkunjung ke Dinas Kependudukan dan Catatan Sipil karena sudah mengenal secara pribadi kepada petugas pelayanan sipil itu sendiri terasa pelayanannya bisa dikatakan semi-formal.

Penelitian menunjukan bahwa pemberian uang ucapan terima kasih ini masih tetap ada, di mulai dari tingkatan pemerintahan di RT, Desa, Kecamatan sampai dengan Dinas Kependudukan dan Catatan Sipil. Pembahasan dalam penelitian ini lebih berfokus pada Dinas Kependudukan dan Catatan Sipil karena sebagai salah satu lembaga pemerintahan yang menampung kebutuhan masyarakat berkaitan dengan pelayanan sipil. untuk di kelas kecamatan dan desa, sesuai dengan hasil penelitian bahwa pihak tersebut hanya mengurusi pengantar surat untuk pembuatan dokumen kependudukan dan catatan sipil yang ada di Dinas Kependudukan dan Catatan Sipil.

Masyarakat banyaknya mengetahui bahwa praktik memberikan uang ucapan terima kasih itu masih ada pada saat pelayanan sipil berlangsung, dan masyarakat juga tidak terlalu mempermasalahkan apabila dalam memberikan gratifikasi dalam bentuk memberikan uang ucapan terima kasih 
ini apabila dalam pemberiannya tidak dalam ranah sogok ataupun pelicin. Karena apabila dalam ranah sogok dan pelicin sudah tidak ada lagi hal yang seperti itu ketika peneliti melakukan observasi di lapangan. Masyarakat juga berpendapat bahwa uang ucapan terima kasih ini terjadi bukan hanya di Dinas Kependudukan dan Catatan Sipil saja, melainkan di setiap elemen masyarakat juga biasanya selalu ada. Hal ini juga dibenarkan oleh pegawai Dinas Kependudukan dan Catatan Sipil sendiri, bahwa perilaku masyarakat dalam memberikan uang ucapan terima kasih ini masih ada di masyarakat, walaupun jumlahnya tidak banyak namun masyarakat ada saja yang memberikan uang ucapan terima kasih karena telah di bantu dalam pengadaan dokumen kependudukan ataupun catatan sipil.

Walaupun ada dari sekian masyarakat yang memberikan uang ucapan terima kasih pada saat pelayanan sipil, tidak membuat regulasi ataupun keputusan dalam pembuatan dokumen kependudukan dan catatan sipil di percepat. Ini seperti yang di ungkapkan oleh kedua informan yang bekerja di Dinas Kependudukan dan Catatan Sipil bahwa mau memberikan uang ataupun tidak pelayanan tetap pada jalur birokrasi yang sama, semua harus sesuai dengan prosedur dan tahapan. Dan apabila mau cepat seharusnya berkas yang di berikan ketika mendaftar di Dinas Kependudukan dan Catatan Sipil itu lengkap dan tidak meragukan. Maka apabila kriteria tersebut terdapat pada berkas masyarakat, pembuatan dokumen kependudukan dan catatan sipil pun akan lebih cepat sesuai dengan proses yang seharusnya di jalani. Adapula anggapan masyarakat yang mengatakan bahwa apabila dengan memberikan uang ucapan terima kasih maka proses pembuatan dokumen kependudukan akan lebih cepat itu hanyalah sebuah paradigma lama, dan hal itu sudah tidak berlaku lagi di Dinas Kependudukan dan Catatan Sipil. Dinas Kependudukan dan Catatan Sipil sendiri sedang gencar-gencarnya menghimbau masyarakat untuk membuat dokumen kependudukan dan catatan sipil karena tidak di pungut biaya dan ini merupakan kewajiban dari warga negara yang baik.

\section{Faktor Budaya yang Memengaruhi Perilaku Gratifikasi dalam Pelayanan Sipil (Civil Service)}

Pada dasarnya perilaku gratifikasi pada pelayanan sipil di Cianjur bukanlah sebuah budaya masyarakat, melainkan hanya kebiasaan masyarakat yang di pengaruhi faktor-faktor budaya pada kehidupan sehari-harinya. Gratifikasi yang dimaksud adalah berbentuk pemberian uang ucapan terima kasih yang masih di temukan pada pelayanan sipil atau bahkan pelayanan administrasi yang lainnya. Pada dasarnya pelayanan sipil sendiri tidak dipungut biaya sepeserpun karena merupakan hak dasariah setiap warga negara Indonesia. Adapun apabila itu dipungut biaya hanya pada pembuatan akta kelahiran apabila 40hari pasca kelahiran tidak membuat akta kelahiran sesuai dengan perda nomor 8 Tahun 2012 tentang retribusi penggantian biaya cetak kartu tanda penduduk dan akta catatan sipil. Kurangnya pemahaman masyarakat mengenai gratifikasi ini membuat masyarakat masih sering memberikan uang ucapan terima kasih pada saat pembuatan dokumen kependudukan dan catatan sipil yang seharusnya tanpa di pungut biaya sepeserpun.

Memberikan uang ucapan terima kasih sendiri merupakan kebiasaan 
masyarakat yang sudah membudaya dari generasi ke generasinya, hal ini dikarenakan karena masyarakat khususnya masyarakat Cianjur yang sangat apresiatif dan rasa saling memiliki antara sesamanya masih tergolong baik. Seperti yang di ungkapkan informan bapak Adam seorang budayawan Cianjur yang mengungkapkan bahwa "apabila dalam pengertian ucapan terima kasih yang asali, itu baru budaya kita sebagai masyarakat Cianjur pada khususnya. Masyarakat Cianjur pada khususnya adalah Orang orang yang pandai dan apresiatif, apapun bentuknya (memberikan bantuan) mengucapkan terima kasih (baik dalam bentuk materi ataupun tidak)". Namun bapak Adam menegaskan bahwa apabila mengucapkan uang ucapan terima kasih dalam artian sogok tentu saja itu bukan sebuah budaya yang berkembang di masyarakat.

Informan selanjutnya bapak Asep mengungkapkan memberikan uang terima kasih ini merupakan sebuah tradisi masyarakat yang berkembang, pendapat ini juga di pertegas oleh informan lainnya yang mengungkapkan bahwasanya memberikan uang ucapan terima kasih ini sebagai bentuk dari rasa terima kasih dan uang jasa karena sudah di berikan bantuan satu sama lainnya walaupun sebenarnya tidak hanya dalam berbentuk uang saja, bisa dalam bentuk lainnya seperti makanan, barang dan lain-lain. Informan yang bertugas di Dinas Kependudukan dan Catatan Sipil sendiri tidak menampik bahwa masih ada gratifikasi yang di terima petugas yang bekerja di dinas kependudukan sendiri, beliau mengungkapkan bahwa itu merupakan sebuah norma yang ada di masyarakat. Beliau mengungkapkan bahwa karena adanya budaya ketimuran di masyarakat, sehingga masyarakat yang sudah di bantu tersebut mengapresiasi dengan memberikan uang ucapan terima kasih yang lazimnya tidak dalam nominal yang besar dan petugas pun tidak memintanya.

Kebiasaan

masyarakat memberikan uang ucapan terima kasih pada pelayanan sipil menurut masyarakat sudah berlangsung sejak lama, karena pada dasarnya kebiasaan ini terintegrasi dengan kebiasaan masyarakat ada kehidupan sehari hari sehingga membudaya bahkan tidak jarang pada saat pelayanan sipil sekalipun. Menurut informan bapak Wawan "dalam masyarakat sudah seperti sekulit sedaging, setiap kantor walaupun tidak semuanya pasti ada hal semacam ini. Tetapi rata-rata ya seperti itu, selalu ada uang gratifikasi".

Perilaku memberikan uang ucapan terima kasih atau dalam bentuk barang atau materi yang lainnya secara tidak langsung di sosialisasikan masyarakat dari setiap generasinya. Berdasarkan hasil penelitian, adanya doktrin agama yang mengatakan bahwa memberikan rezeki kepada orang lain itu merupakan sebuah ibadah di mana saling memberi untuk menyambung tali silaturahmi, dan dalam pengertian seperti itu masyarakat menanggapnya sebagai sebuah sedekah yang wajar saja di lakukan walaupun itu pada pelayanan sipil. "tangan di atas lebih baik dari pada tangan di bawah" juga "tidak boleh menolak rezeki" merupakan mazhab yang di pegang oleh masyarakat dan juga petugas pelayanan sipil untuk saling menerima dan memberi uang ucapan terima kasih.

Pengalaman masyarakat dalam pelayanan sipil ketika belum di perbaharui sesuai dengan UndangUndang Nomor 23 Tahun 2006 tentang Administrasi Kependudukan pun 
melandasi adanya perilaku memberikan uang ucapan terima kasih pada pelayanan sipil. Perilaku gratifikasi ini dikarenakan adanya pengalaman masyarakat ketika membuat dokumen kependudukan dan catatan sipil di kecamatan merasa bahwa pelayanan tanpa adanya uang ucapan terima kasih terasa sangat tidak prima dan cenderung di hambat, seperti pengalaman informan bapak Febbi yang mengungkapkan bahwa "ketika melakukan pembuatan catatan sipil, memang kalau tidak di sertai uang ucapan terima kasih justru malah prosesnya lama di bandingkan dengan memberikannya". Tidak hanya itu, bapak Wawan sebagai perangkat desa juga menjelaskan bahwasanya gratifikasi ini "...kebiasaan masyarakat, saya kan baru sepuluh tahun di kantor, dan dari generasi sebelumnya pun selalu melakukan hal yang seperti itu". Pernyataan bapak Wawan menegaskan bahwa pada dasarnya gratifikasi memang membuat petugas dari pelayanan sipil sendiri menjadi lebih prima dari pada tidak melakukan gratifikasi.

Pendapat informan lainnya yang masih beranggapan dengan memberikan uang ucapan terima kasih ini dapat memperlancar dan membuat petugas pelayanan sipil lebih baik dari segi pelayanan. Namun hal ini sudah tidak berlaku lagi, seperti penuturan dari informan yang berkerja di Dinas Kependudukan dan Catatan Sipil yang menjelaskan bahwa dengan ada atau tidak adanya gratifikasi semua pelayanan sipil itu sama tidak di bedabedakan, tidak ada diskriminasi asalkan sesuai dengan prosedur dan berkasberkas yang diberikan lengkap serta tidak meragukan. Hal ini juga terlihat ketika peneliti melakukan observasi di lapangan yang mengambil kesimpulan bahwa praktik seperti itu sangat kecil kemungkinannya karena dilihat dari segi pelayanan yang lebih apik dan teratur.

\section{PEMBAHASAN \\ Pemahaman Masyarakat Mengenai Gratifikasi}

Masyarakat pada umumnya tidak begitu memahami apa yang dimaksud dengan gratifikasi apalagi yang berkaitan dengan sektor pelayanan sipil. Gratifikasi sebagai korupsi apabila gratifikasi dimaksudkan untuk mempercepat proses pelayanan sipil. Gratifikasi sendiri secara etimologis bersal dari bahasa Belanda "gratikatie" yang diadopsi dalam bahasa Inggris menjadi "gratification" yang artinya "pemberian sesuatu/hadiah". Dalam hal ini memang terkadang masyarakat sulit membedakan antara "hadiah (gift) dengan suap (bribe)". Masyarakat memahami bahwa memberikan uang ucapan terima kasih merupakan bentuk dari interaksi yang bermuatan positif secara nilai dan norma sosial yang berlaku di masyarakat.

Menurut Setiadi nilai didefinisikan sebagai "kumpulan sikap perasaan ataupun anggapan terhadap sesuatu hal tentang baik buruk, benar salah, patut tidak patut, hina mulia, maupun penting tidak penting" (2010, hlm.118). Perilaku memberikan uang ucapan terima kasih dianggap sebuah perilaku yang baik dan patut dilakukan oleh masyarakat yang merupakan ekspresi dari apresiasi masyarakat sebagai timbal balik karena bantuan yang telah diberikan oleh orang lain. Seperti yang diungkapkan Horton dan Hunt bahwa "nilai adalah gagasan tentang apakah pengalaman itu berarti atau tidak". Pengalaman gratifikasi pada pelayanan sipil baik dilihat dari penerima maupun pemberi mempunyai nilai yang berarti bagi masing-masing masyarakat, di mana pihak penerima mendapatkan 
nilai secara material dan pemberi mendapatkan kepuasan kerohanian.

Nilai material yang diterima petugas pelayanan sipil yaitu berupa uang yang diberikan oleh masyarakat, uang tersebut dapat begitu bernilai bagi petugas pelayanan sipil. Masyarakat yang memberikan uang ucapan terima kasih meraih nilai-nilai kerohanian seperti nilai kebenaran yang bersumber pada rasio (akal), dimana masyarakat memahami bahwa memberikan uang ucapan terima kasih benar untuk dilakukan, serta nilai moral yang bersumber kepada kehendak, yang tidak terlepas dari individu masingmasing yang menganggap bahwa perilaku memberikan uang ucapan terima kasih ini memang baik dan patut dilakukan khususnya dalam penelitian ini pada pelayanan sipil.

Melihat dari sudut pandang norma yang berlaku, memberikan uang ucapan terima kasih merupakan sebuah perilaku yang diatur oleh norma yang membuat masyarakat secara otomatis berperilaku demikian, gratifikasi sendiri khususnya dalam pelayanan sipil merupakan sebuah kebiasaan (folkways) masyarakat yang dilandasi dari kehidupan sehari-harinya. Menurut Maclver dan Page (dalam Soekanto, 2002, hlm 201) kebiasaan merupakan perilaku yang diakui dan diterima oleh masyarakat, apabila kebiasaan tersebut tidak semata-mata dianggap sebagai cara perilaku saja. Akan tetapi bahkan diterima sebagai norma-norma pengatur, maka disebutkan kebiasaan tadi sebagai Mores atau tata kelakuan. Hasil penelitian mengungkapkan bahwa memberikan uang ucapan terima kasih menjadi sebuah keharusan bagi masyarakat yang terdorong karena norma yang berlaku di masyarakat itu sendiri. Masyarakat memberikan uang ucapan terima kasih ini dikarenakanmemang sudah seharusnya ketika di beri bantuan/dilayani oleh orang lain masyarakat memberikan imbalan sebagai bentuk apresiasi atas bantuan yang telah diberikan. Bagi petugas pelayan sipil sendiri, menolak merupakan sebuah pilihan perilaku yang sangat berlainan dengan norma yang ada di masyarakat karena akan berakibat rasa tidak enak karena menolak pemberian dari masyarakat.

Walaupun secara nilai dan norma sosial memberikan uang ucapan terima kasih ini merupakan sebuah perilaku yang baik dan patut dilakukan. Akan tetapi dalam pelayanan sipil sendiri memang secara norma hukum yang berlaku sudah diatur bahwasanya dalam pembuatan seperti KTP, KK, akta dan lain-lain khususnya pada pelayanan sipil untuk masyarakat dan petugas untuk tidak memberikan uang ucapan terima kasih. Tujuan dari diaturnya gratifikasi ini tidak lain untuk melindungi masyarakat sendiri agar tidak terjadi penyalahgunaan wewenang dari aparat pemerintahan juga untuk mengurangi potensi adanya praktik korupsi yang berkedok uang ucapan terima kasih di kemudian hari. Gratifikasi itu sendiri bisa dikatakan sebagai suap pasif sebagaimana dijelaskan dalam rumusan UU Nomor 20 Tahun 2001 tentang perubahan UU nomor 31 tahun 1999 tentang pemberantasan tindak pidana korupsi, Pasal 3 Peraturan Pemerintah Nomor 53 tahun 2010 tentang Peraturan Disiplin Pegawai Negeri Sipil, Pasal 4 PP No. 53 Tahun 2010 mengatur larangan bagi setiap PNS serta tidak sesuai dengan Pasal 2 UU nomor 25 tahun 2009 tentang pelayanan publik. 
Persepsi Masyarakat Mengenai Perilaku Gratifikasi dalam Pelayanan Sipil (Civil Service)

Perilaku masyarakat melakukan gratifikasi pada pelayanan sipil dipengaruhi oleh persepsi masyarakat terhadap perilaku gratifikasi tersebut, dalam hal ini memberikan uang ucapan terima kasih pada pelayanan sipil. Walgito (2004, hlm.70) mengungkapkan bahwa "persepsi merupakan suatu proses pengorganisasian, penginterpretasian terhadap stimulus yang diterima oleh organisme atau individu sehingga menjadi sesuatu yang berarti, dan merupakan aktivitas yang terintegrasi dalam diri individu". Bedasarkan hal tersebut, perasaan, kemampuan berpikir, pengalamanpengalaman masyarakat yang berbeda akan menghasilkan persepsi yang berbeda.

Berdasarkan penelitian, secara garis besar terdapat tiga point persepsi yang melandasi masyarakat. Pertama, masyarakat memiliki persepsi apabila tidak memberikan uang ucapan terima kasih merasa dirinya atau orang lain yang melakukannya akan malu untuk pergi dan memang seharusnya apabila sudah dibantu hendaknya memberikan uang ucapan terima kasih sebagai tanda jasa. Kedua, adanya empati kepada petugas pelayanan sipil membuat masyarakat merasa kasihan dan memberikan uang ucapan terima kasih ini sebagai bagian dari menjalankan ibadah yaitu sedekah. Ketiga, gratifikasi dilakukan karena pengalaman pribadi mereka yang apabila tidak memberikan uang ucapan terima kasih ini pelayanan dirasa tidak memuaskan sehingga mereka memberikan uang ucapan terima kasih bertujuan agar pelayanan dapat maksimal dan cepat. Hal-hal yang di ungkapkan tersebut membentuk sebuah persepsi pada masyarakat dalam perilaku gratifikasi pada pelayanan sipil karena merupakan sebuah objek yang terbiasakan oleh masyarakat selaras dengan pengetahuan, pengalaman serta cara berpikir masyarakat sehari-hari.

Persepsi di konstruksi berdasarkan beberapa hal seperti yang dikemukakan oleh Thoha (2003, hlm. 154), faktor-faktor yang mempengaruhi persepsi seseorang adalah sebagai berikut;

1. Faktor internal: perasaan, sikap dan kepribadian individu, prasangka, keinginan atau harapan, perhatian (fokus), proses belajar, keadaan fisik, gangguan kejiwaan, nilai dan kebutuhan juga minat, dan motivasi.l

2. Faktor eksternal: latar belakang keluarga, informasi yang diperoleh, pengetahuan dan kebutuhan sekitar, intensitas, ukuran, keberlawanan, pengulangan gerak, hal-hal baru dan familiar atau ketidak asingan suatu objek.

Dalam penelitian persepsi ini persepsinya sendiri dapat dilihat dari dua sudut pandang yang berbeda. Internal, berkaitan dengan diri individu yang memiliki dorongan untuk melakukan gratifikasi khususnya pada pelayanan sipil, menurut data yang telah dikumpulkan, faktor internal ini berkenaan dengan beberapa hal yang mendasari perilaku tersebut. Adanya sikap malu apabila tidak memberikan uang ucapan terima kasih karena beranggapan setelah seseorang membantu memang seharusnya memberikan imbalan yang biasanya dalam pelayanan sipil ini berupa uang ucapan terima kasih, selain itu juga rasa 
simpati dan empati masyarakat mendorong masyarakat untuk memberikan uang ucapan terima kasih sebagai salah satu bentuk sedekah karena merasa kasihan terhadap petugas pelayanan sipil sendiri. Adapula yang berlandaskan pengalaman pribadinya yang merasa tidak dilayani dengan baik apabila tidak memberikan uang ucapan terima kasih sehingga mendorong mereka untuk melakukan gratifikasi pada pelayanan sipil.

Eksternal, berkaitan dengan dorongan-dorongan yang berada di luar diri individu. Adanya kebiasaan masyarakat untuk memberikan uang ucapan terima kasih pada saat dibantu oleh orang lain sebagai bentuk apresiasi karena sudah di bantu walau tidak hanya berupa materi saja. Selain itu juga norma sosial yang kondusif akan gratifikasi dan menganggap itu sebagai uang tips ataupun fee sehingga tidak dianggap sebagai sebuah penyimpangan ada saat pelayanan sipil, padahal sebenarnya itu sudah tidak relevan lagi apabila di bawa kepada aspek pemerintahan khususnya pada pelayanan sipil yang memiliki prinsip pure no price. Perilaku gratifikasi pada pelayanan sipil sendiri dikaitkan dengan norma agama yaitu sebagai bentuk dari sedekah dan untuk menjalin silaturahmi antara sesama manusia, petugas pelayanan sipil juga merasa bahwa menerima uang ucapan terima kasih ini bukanlah sebuah masalah karena "tidak baik menolak rezeki”, dan ada rasa tidak nyaman ketika harus menolak pemberian dari orang lain.

Persepsi masyarakat terhadap perilaku gratifikasi pada pelayanan sipil juga ditinjau dari teori pertukaran perilaku (Social Exchange) George Homans yang mengemukakan beberapa proposisinya. Pertama, Proposisi Sukses "Untuk semua tindakan yang dilakukan seseorang, semakin sering tindakan khusus seseorang diberi hadiah, semakin besar kemungkinan orang melakukan tindakan itu" (Polloma, 2004, hlm.16). Dalam kaitannya dengan perilaku gratifikasi pada pelayanan sipil, perilaku yang dilakukan oleh petugas pelayanan sipil yaitu memberikan pelayanan yang baik bagi masyarakat, walau sebenarnya sudah menjadi kewajiban bagi pelayanan sipil untuk memberikan pelayanan yang baik, seperti data yang telah dikumpulkan yang merujuk bahwa pelayanan sipil yang biasanya diberikan gratifikasi itu ketika bentuk pelayanannya biasa terjadi karena masyarakat membutuhkan bimbingan atau pelayanan yang personal dalam artian masyarakat meminta petugas untuk diberi petunjuk secara langsung oleh petugas dalam memenuhi berkas persyaratan membuat dokumen kependudukan atau catatan sipil, sehingga terjalin sebuah keterikatan yang berkonsekuensi pada rasa tidak enak masyarakat apabila tidak membalas dengan sebuah perilaku yang menguntungkan petugas pelayanan sipil sendiri, biasanya dalam bentuk memberikan uang ucapan terima kasih. Bahkan dalam beberapa kasus yang hanya melakukan pelayanan seperti biasanya juga terkadang masyarakat memberikan uang ucapan terima kasih. Petugas pelayanan sipil merasa dapat sebuah keuntungan yang berupa material sehingga perilaku tersebut baik memberikan layanan yang baik ataupun menerima uang ucapan terima kasih tersebut dilakukan.

Kedua, Homans mengungkapkan Proposisi Pendorong (The Stimulus Proposition) "Bila dalam kejadian di masa lalu dorongan tertentu atau sekumpulan dorongan telah menyebabkan tindakan orang diberi 
hadiah, maka makin serupa dorongan kini dengan dorongan di masa lalu, makin besar kemungkinan orang melakukan tindakan serupa" (Poloma, 2004). Proposisi pendorong dalam perilaku gratifikasi pada pelayanan sipil mengungkapkan keterkaitan pengalaman masyarakat dalam kehidupan sehari-hari bahkan dalam pelayanan sipil sendiri yang mendorong masyarakat dalam berperilaku gratifikasi. Pengalaman masyarakat ketika hendak melakukan pembuatan dokumen kependudukan dan atau pencatatan sipil, di mana apabila mereka tidak memberikan uang ucapan terima kasih mereka merasa tidak dilayani dengan baik dan pelayanan cenderung lebih lama, oleh karena itu mereka memberikan uang ucapan terima kasih tersebut dan akhirnya diberikan hadiah oleh petugas pelayanan sipil (berupa pelayanan yang baik dan di rasakan lebih cepat). Dorongan dari pengalaman masyarakat ini yang membuat kemungkinan orang melakukan tindakan gratifikasi yang serupa. Walau pada dasarnya praktik seperti ini (pelayanan yang dipercepat karena di berikan uang ucapan terima kasih apalagi dalam hal keputusan yang ilegal) sudah tidak berlaku lagi di pelayanan sipil khususnya di dinas kependudukan dan catatan sipil.

Ketiga, Proposisi Nilai; "semakin bernilai tindakan seseorang bagi dirinya, semakin besar kemungkinan dia untuk melaksanakan tindakan itu" (Ritzer, 2012, hlm. 720). Nilai yang di maksud tidak hanya yang bersifat materialistik saja, tetapi bisa juga bersifat altruistik. Dalam penelitian kali ini lebih memfokuskan pada nilai yang bersifat materialistik yang biasanya juga akan berkaitan dengan altruistik. Sudah tidak dapat disangkal lagi apabila petugas pelayanan sipil sendiri menerima uang ucapan terima kasih ini dengan tangan terbuka, dan karena pemberian tersebut bernilai bagi petugas pelayanan sipil sendiri dan menganggapnya sebagai uang tip dengan alasan asalkan tidak meminta tentu saja di perbolehkan. Begitu pula bagi masyarakat, adanya pengalaman dari beberapa informan ataupun masyarakat apabila memberikan uang ucapan terima kasih ini biasanya terasa pelayanan lebih baik dari pada sebelumnya. Namun hal ini sudah tidak berlaku lagi pada pelayanan di dinas kependudukan dan catatan sipil, adapun gratifikasi yang diberikan oleh masyarakat biasanya terjadi karena adanya kedekatan secara personal dengan petugas pelayanan sipil ataupun karena masyarakat meminta petugas membantu untuk melengkapi berkas pembuatan dokumen kependudukan dan atau catatan sipil, karena adanya interaksi yang lebih intens dan menimbulkan kedekatan itulah yang membuat masyarakat memberikan uang ucapan terima kasih kepada petugas pelayanan sipil.

Keempat adalah Proposisi Rasionalitas; "dalam memilih di antara tindakan-tindakan alternatif, seseorang akan memilih tindakan, yang dia rasakan pada saat itu, mempunyai nilai hasil (Value), $\mathrm{V}$, yang lebih besar, yang dilipatgandakan oleh kemungkinan mendapat hasil (Probability), P" (Ritzer, 2012, hlm 723). Dalam proposisi ini Homans menghubungkan dengan proposisi-proposisi sukses, stimulus dan nilai. Proposisi Rasionalitas memberitahukan kita bahwa kemungkinan orang melakukan tindakan tergantung pada persepsi mereka atas kemungkinannya untuk berhasil. Tindakan perilaku gratifikasi masyarakat pada pelayanan sipil dalam proposisi rasionalitas bergantung pada persepsi masyarakat itu sendiri, 
persepsi masyarakat menganggap bahwa dengan memberikan uang ucapan terima kasih membuat pelayanan berbeda dan cenderung lebih baik membuat masyarakat mengulangi tindakan tersebut. Walaupun apabila berbicara dalam pelayanan di Dinas Kependudukan dan Catatan Sipil memberikan uang ucapan terima kasih ini tidak berlaku dalam hal kinerja untuk di percepat, namun dapat di generalisasikan pada pelayananpelayanan publik seperti di RT/RW, desa ataupun di kecamatan yang notabene pelayanannya bisa terjadi semi-formal. Homans berargumen bahwa "persepsi-persepsi mengenai apakah peluang-peluang berhasil tinggi atau rendah dibentuk oleh keberhasilan masa lampau" (dalam Ritzer, 2012, hlm 725). Karena pengalaman akan keberhasilan pada masa lampau ini yang membuat masyarakat masih melakukan hal tersebut.

Dasar dari teori George C. Homans sendiri menekankan adanya timbal balik dari sebuah prilaku yang dilakukan individu dengan individu lainnya. Seperti yang sudah di ungkapkan di atas bahwa adanya pertukaran perilaku dari masyarakat dengan petugas pelayanan sipil sendiri yang melandasi adanya perilaku gratifikasi pada pelayanan sipil. Selain itu juga pertukaran perilaku diantara masyarakat dengan calo serta adanya kerja sama di antara calo dan petugas pelayanan sipil untuk membantu masyarakat dengan cara memotong proses dari pembuatan dokumen kependudukan dan catatan sipil masyarakat. Semua perilaku tersebut terkemas dalam sebuah persepsi masyarakat yang berkaitan dengan budaya masyarakat, kebiasaankebiasaan masyarakat di dalam kehidupan sehari-hari, norma-norma yang ada serta kebutuhan masyarakat akan waktu untuk mempersingkat proses pembuatan dokumen kependudukan dan catatan sipil.

\section{Faktor Budaya yang Memengaruhi Perilaku Gratifikasi dalam Pelayanan Sipil (Civil Service)}

Taylor (dalam Sujarwa, 2011, hlm.28) dalam bukunya yang berjudul Primitive Culture dikatakan bahwa "kebudayaan adalah keseluruhan yang kompleks, di dalamnya terkandung ilmu pengetahuan yang lain, serta kebiasaan yang didapat manusia sebagai anggota masyarakat". Pengetahuan yang lain serta kebiasaan yang di dapat oleh manusia mencerminkan bahwasanya adanya nilai dan norma yang menjadi acuan hidup masyarakat yang menjadi terbiasakan oleh individu untuk berperilaku sebagaimana masyarakat pada umumnya. Hal ini terjadi baik disadari oleh individu ataupun tidak, namun tersosialisasikan kepada anggota masyarakat itu sendiri.

Sejalan dengan yang diungkapkan Taylor, Koentjoroningrat (dalam Notowidagdo, 2002, hlm.26) mengatakan bahwa "kebudayaan itu adalah keseluruhan kelakuan dan hasil kelakuan manusia yang diatur oleh tata kelakuan yang harus didapatkannya dalam belajar dan semuanya tersusun dalam kehidupan masyarakat". Menurut penjelasan dari Koentjoroningrat mengenai kelakuan dan hasil kelakuan manusia yang diatur oleh tata kelakuan merujuk pada nilai dan norma yang dianut oleh masyarakat. Seperti halnya dalam perilaku gratifikasi pada pelayanan sipil, bahwasanya adanya perilaku seperti memberikan uang ucapan terima kasih juga karena di dukung oleh nilai dan norma yang ada di masyarakat. Hasil penelitian mengungkapkan bahwasanya adanya 
kebiasaan

masyarakat

yang memberikan uang ucapan terima kasih ini dikarenakan adanya nilai yang menganggap bahwa ketika di berikan bantuan sudah seharusnya membalas bantuan tersebut. Hal ini dilakukan karena untuk menjalin tali silaturahmi dan perasaan ingin membantu sesama masyarakat Cianjur. Selain itu juga masyarakat menganggapnya sebagai bagian dari pada sedekah yang dianjurkan oleh agama terhadap sesama umat manusia. Adanya rasa empati masyarakat terhadap petugas pelayanan sipil sendiri juga yang melandasi adanya perilaku tersebut yang membuat perilaku gratifikasi pada pelayanan sipil tetap ada karena pada dasarnya kebiasaan ini sudah secara masif membudaya di masyarakat.

Perilaku gratifikasi yang ada di masyarakat menggambarkan bahwa masyarakat Cianjur merupakan masyarakat yang memiliki "Kebudayaan yang mementingkan hubungan horizontal akan menjalin hubungan baik dengan tetangga dan sesamanya, karena hal itu dianggap penting dalam hidup." (Sujarwa, 2011, hIm.37). Karena menjalin hubungan dengan sesama masyarakat itu dianggap penting dalam hidup, dalam penelitian ini perilaku gratifikasi pada pelayanan sipil sendiri merupakan salah satu bentuk dari menjalin hubungan baik di antara sesama.

Budaya masyarakat yang apresiatif tersebut masih terus ada di dalam kehidupan masyarakat bahkan terbawa sampai pada pelayanan sipil sendiri. Surajwa (2011, hlm.32) mengungkapkan bahwa "adapun proses pewarisannya (Budaya) ditransmisikan dengan cara belajar dari apa yang telah tersusun dalam kehidupan di masyarakat". Secara tidak langsung adanya nilai dan norma yang ada di masyarakat yang mengatur kehidupan masyarakat.

Mengacu pada penjelasan tersebut, peneliti menggunakan teori penyimpangan sosial sosialisasi (asosiasi diferensial) yang diungkapkan oleh Shuterland untuk menjelaskan permasalahan yang berkaitan dengan gratifikasi pada pelayanan sipil. Teori ini mengungkapkan bahwa penyimpangan perilaku merupakan hasil dari proses belajar yang dipelajari di lingkungan sosial.

Proposisi pertama shuterland mengungkapkan bahwa "Prilaku menyimpang adalah hasil dari proses belajar atau yang dipelajari". Dengan demikian bahwa penyimpangan bukanlah sesuatu yang diwariskan atau diturunkan atau bahkan konsekuensi dari intelegensi yang rendah, namun justru karena penyimpangan ini hasil dari proses belajar atau yang dipelajari.

Kedua, "Prilaku menyimpang dipelajari oleh seseorang dalam interaksinya dengan orang lain dari komunikasi". Adanya interaksi tersebut akan menjadi terinternalisasi oleh seorang individu melalui komunikasi diantara individu dengan lingkungan di sekitar individu tersebut. Dalam proposisi kedua ini berkaitan dengan proposisi selanjutnya yang berkaitan dengan bagian utama dalam proses belajar perilaku ini yang terjadi di dalam kelompok-kelompok personal yang komunikasi dalam kelompok tersebut terjalin secara intim dan akrab yang memudahkan proses internalisasi perilaku.

Ketiga, yaitu "Bagian utama dari belajar tentang prilaku menyimpang terjadi di dalam kelompok-kelompok personal yang intim atau akrab". Ketiga proposisi yang dijelaskan di atas merupakan proses pembentukan dasar dari adanya perilaku gratifikasi pada 
pelayanan sipil yang terjadi di masyarakat. Menurut hasil penelitian bahwa masyarakat melakukan perilaku gratifikasi dikarenakan adanya sebuah pembelajaran yang di dapatkan dalam kehidupan bermasyarakat, hal ini diungkapkan bahwasanya bentuk proses belajar atau mempelajarinya tersebut dapat secara langsung ataupun tidak langsung. Adanya penurunan nilai dan norma yang ada dimasyarakat juga memengaruhi proses belajar individu dalam berperilaku gratifikasi khususnya pada pelayanan sipil. Petugas pelayanan sipil yang menerima uang ucapan terima kasih juga tidak luput dari adanya proses belajar di lingkungan sekitar kantor dan lingkungan masyarakat. Petugas mengaku bahwa mereka menerima uang ucapan terima kasih dikarenakan adanya perilaku tersebut yang dibiasakan sejak dahulu oleh petugas yang lebih lama bertugas di pelayanan sipil. Selain itu juga tidak adanya peraturan yang di sosialisasikan oleh atasan mengenai tidak boleh menerima uang dalam bentuk apapun juga membuat petugas pelayanan sipil sendiri tetap menerima uang ucapan terima kasih dari masyarakat. Walaupun sebenarnya tidak diperbolehkan menerima uang ucapan terima kasih pada pelayanan sipil sesuai dengan ketentuan KPK.

Proposisi Keempat yang diungkapkan Shuterland yaitu "Hal-hal yang dipelajari di dalam proses terbentuknya prilaku menyimpang yaitu: (1) teknis-teknis penyimpangan, yang kadang-kadang sangat rumit, tetapi kadang-kadang juga cukup sederhana;

(2) petunjuk-petunjuk khusus tentang motif, dorongan, rasionalisasi dan sikapsikap berprilaku menyimpang". Perilaku gratifikasi pada pelayanan sipil biasanya di tunjukan pada motif agar dipercepat dan pelayanan semakin baik, dan dilandasi dengan dorongan bahwa memberikan uang ucapan terima kasih ini dianggapp sebagai sedekah yang tidak berarti melanggar secara peraturan hukum. Selain itu juga terbentuknya rasionalisasi masyarakat yang memersepsikan bahwa setiap perlakuan yang baik dari orang lain harus ada imbalan, begitu juga pada saat pelayanan sipil, ketika masyarakat dirasa puas dengan sebuah pelayanan yang ada di pelayanan sipil mereka secara otomatis memberikan uang ucapan terima kasih yang di dorong dengan inisiatif masyarakat.

Proposisi kelima, "Petunjukpetunjuk khusus tentang motif dan dorongan untuk berprilaku menyimpang itu dipelajari dari definisi-definisi tentang norma-norma yang baik atau tidak baik". Pernyataan dalam proposisi kelima ini menjelaskan bahwa di masyarakat memberikan uang ucapan terima kasih ini merupakan hal yang di dasari oleh norma-norma yang didefinisikan oleh masyarakat sebagai sesuatu yang baik sehingga perilaku seperti ini tetap ada di dalam pelayanan sipil, dengan catatan bahwa memberikan uang ucapan terima kasih ini tidak dalam konteks suap ataupun sogokan. Hal ini dikarenakan norma-norma yang mengatur di masyarakat juga tidak menampikan bahwa perilaku ini buruk dan tidak pantas dilakukan, adanya dorongan norma sosial dan agama di masyarakat bahwa memberi itu lebih baik dari pada menerima serta sebagai salah satu sarana ibadah yaitu sedekah dan adanya pendefinisian ketika telah dibantukan alangkah baiknya memberikan imbalan membuat perilaku gratifikasi pada pelayanan sipil masih berlangsung. Seperti yang di gambarkan oleh Santoso dan Zulfa bahwa; 
Di beberapa masyarakat individu di kelilingi orang-orang yang tanpa kecuali mendefinisikan aturan aturan hukum sebagai aturan yang harus dijalankan, sementara di tempat lain di kelilingi oleh orangorang yang definisi-definisinya menguntungkan untuk melanggar aturan-aturan hukum. Tidak setiap orang dalam maysarkat setuju bahwa hukum harus ditaati. Beberapa orang mendefinisikan aturan hukum sebagai tidak penting (Santoso \& Zulfa, 2001, hIm 76)

Proposisi keenam Shuterland mengungkapkan bahwa "Seseorang menjadi menyimpang karena menganggap lebih menguntungkan melanggar norma (deviant) daripada tidak (conform)". yang perlu di garis bawahi bahwa deviant yang dimaksud adalah dalam hal norma hukum, di sini petugas jikalaupun di hadapkan dengan masyarakat yang memberikan uang ucapan terima kasih ini akan lebih cenderung menerimanya. Seperti yang di ungkapkan informan yang bekerja di Dinas Kependudukan dan Catatan Sipil bahwa sedikitnya petugas memang merasa menerima uang ucapan terima kasih melanggar hukum karena di dukung dengan banyaknya banner dan pengumuman bahwa dalam pelayanan sipil ini tidak memungut biaya, akan tetapi petugas juga merasa bahwa menolak pemberian dari masyarakat juga membuat mereka merasa tidak nyaman dan lebih memilih untuk menerima uang tersebut dari pada tidak, selain merasa di untungkan secara materi, petugas juga merasa tidak melanggar tata krama yang sebaiknya menerima pemberian dari orang lain dari pada tidak menerimanya.
Proposisi ketujuh, "Terbentuknya asosiasi diferensial itu bervariasi tergantung dari frekuensi, durasi, prioritas dan intensitas". Artinya dalam penyimpangan perilaku gratifikasi ini tidak berlaku untuk semua masyarakat Cianjur akan tetapi untuk beberapa kasus masyarakat yang memberikan uang ucapan terima kasih ini dapat di kaji dari teori asosiasi diferensial.

Proposisi kedelapan, "Proses mempelajari penyimpangan perilaku melalui kelompok yang memiliki polapola menyimpang atau sebaliknya, melibatkan semua mekanisme yang berlaku di dalam setiap proses belajar". Dalam penelitian mengenai gratifikasi ini penyimpangan perilaku secara hukum terjadi karena adanya sebuah mekanisme norma sosial yang berlaku di masyarakat sehingga individu menyesuaikan diri dengan mekanisme tersebut. Semua perilaku gratifikasi pada pelayanan sipil dipengaruhi oleh proses belajar masyarakat mengenai mekanisme norma tersebut. Baik yang dipelajari pada kehidupan sehari hari mengenai gratifikasi ataupun seperti yang di ungkapkan dalam penelitian mekanisme tersebut terjadi pada pelayanan sipil yang mengisyaratkan bahwa adanya kebiasaan lama yang masih berlanjut sehingga mendorong masyarakat memberikan uang ucapan terima kasih, begitu pula dengan petugas pelayanan sipil yang menerima uang ucapan terima kasih tersebut.

Proposisi kesembilan, "Meskipun prilaku menyimpang merupakan salah satu ekspresi dari kebutuhan dan nilainilai masyarakat yang umum, tetapi penyimpangan prilaku tersebut tidak dapat dijelaskan melalui kebutuhan dan nilai-nilai umum tersebut". Walaupun pada dasarnya budaya perilaku gratifikasi seperti ini sudah tidak relevan apabila di tarik dalam sebuah pelayanan 
sipil akan tetapi permasalahan ini masih berlangsung karena adanya sebuah dorongan moral dan kebiasaan masyarakat akan perilaku gratifikasi tersebut. Oleh karenanya perilaku gratifikasi pada pelayanan sipil ini akan sulit apabila di kaji melalui kebutuhan dan nilai-nilai keumuman yang ada di masyarakat khususnya pada pelayanan sipil sendiri.

Menurut teori asosiasi diferensial prilaku menyimpang tersebut dapat kita pelajari melalui interaksi dan komunikasi, yang dipelajari dalam kelompok tersebut adalah teknik untuk melakukan penyimpangan dan alasan-alasan (nilai-nilai, motif rasionalisasi, serta tingkah laku) yang mendukung perbuatan menyimpang tersebut. (Anwar dan Adang, 2010, hlm 77)

Berdasarkan pemaparan di atas mengenai perilaku gratifikasi pada pelayanan sipil yang dikaji melalui teori

\section{SIMPULAN}

Masyarakat pada umumnya bahkan petugas pelayanan sipil sendiri tidak mengetahui apa yang dimaksud dengan gratifikas dan menganggap bahwa memberikan uang ucapan terima kasih bukanlah sebuah pelanggaran. Dilihat dari sudut pandang nilai dan norma sosial di masyarakat bahwa memberikan uang ucapan terima kasih merupakan hal yang baik untuk mempererat tali silaturahmi, sarana beribadah yaitu sedekah, dan sebagi bentuk apresiasi karena sudah di layani dengan baik. Padahal menurut KPK memberikan uang ucapan terima kasih walaupun memberikannya secara sukarela dan tulus hati kepada petugas layanan, tetapi pemberian tersebut dapat dikategorikan sebagai pemberian yang berhubungan dengan jabatan dan asosiasi diferensial Shuterland, bahwa perilaku gratifikasi pada pelayanan sipil ini merupakan sebuah perilaku hasil dari adanya kebiasaan masyarakat yang di landaskan oleh alasan-alasan (nilainilai, motif rasionalisasi, serta tingkah laku) untuk melakukan sebuah penyimpangan secara hukum yang berlaku. Dalam hal ini adanya persepsi masyarakat yang kuat mengenai uang ucapan terima kasih juga norma-norma sosial serta budaya yang mengatur masyarakat menjadi sebuah landasan mengapa perilaku gratifikasi pada pelayanan sipil sendiri masih ada di masyarakat, yang idealnya perilaku gratifikasi pada pelayanan sipil sendiri seharusnya di hilangkan karena berkaitan dengan profesionalisme petugas pelayanan sipil yang memang seharusnya memberikan pelayanan yang baik bagi masyarakat juga untuk menghindari adanya persepsi negatif dari masyarakat mengenai pelayanan sipil.

berkaitan dengan kewajiban penyelenggara negara/pegawai negeri yang berarti melanggar UU Nomor 20 Tahun 2001 tentang perubahan UU nomor 31 tahun 1999 tentang pemberantasan tindak pidana korupsi serta menyalahi Pasal 2 UU nomor 25 tahun 2009 tentang pelayanan publik.

Adanya persepsi bahwa dengan memberikan uang ucapan terima kasih akan membuat pelayanan berjalan dengan lancar dan lebih baik memperkuat perilaku gratifikasi ini tetap berlangsung. Perilaku memberikan uang ucapan terima kasih juga merupakan pertukaran perilaku yang dilakukan di antara masyarakat dengan petugas pelayanan sipil yang di dasari persepsi masyarakat yang seolah mengharuskan memberikan uang ucapan terima kasih tersebut, sehingga 
masyarakat yang telah dilayani memberikan uang ucapan terima kasih sebagai tanda telah di layani dengan baik.

Memberikan uang ucapan terima kasih merupakan sebuah budaya yang telah terbiasakan oleh masyarakat dalam kehidupan sehari-hari. Kebiasaan ini berdasarkan nilai dan norma yang berlaku di masyarakat yang terinternalisasi ke dalam kehidupan sehari-hari. Walaupun sebenarnya kebiasaan memberikan uang ucapan terima kasih ini sudah tidak relevan apabila dilakukan pada sektor-sektor pelayanan pemerintahan yang dalam penelitian ini yaitu sektor pelayanan sipil. Perilaku memberikan uang ucapan terima kasih yang di lakukan masyarakat merupakan hasil proses belajar individu dalam lingkungannya, yang terinternalisasi karena mendukungnya lingkungan masyarakat untuk berperilaku seperti memberikan uang ucapan terima kasih dalam kehidupan masyarakat sesuai dengan pembahasan teori asosiasi diferensial.

\section{DAFTAR PUSTAKA}

Anwar, Y. \& Adang. (2010). Kriminologi. Bandung: PT Rafika Aditama.

Koentjaraningrat. (2009). Pengantar IImu Antropologi. Jakarta: PT Rineka Cipta.

Komisi Pemberantasan Korupsi. Gratifikasi Tanya Jawab Gratifikasi. [Online]. Tersedia: http://kpk.go.id/ gratifikasi/ index.php /informasigratifikasi/ tanya-jawab-gratifikasi. [Diakses 26 Oktober 2014]

Ndraha, T. (2003). Kybernologi (ilmu pemerintahan baru) I\&II. Jakarta: Rineka Cipta.

Notowidagdo, Rohiman H. (2002). IImu Budaya Dasar Berdasarkan Al-
Quran dan Hadist. Jakarta: Raja Grafindo Persada

Pasal 2 UU nomor 25 tahun 2009 tentang Pelaksanaan dalam Pelayanan Publik

Pasal 3 Peraturan Pemerintah Nomor 53 Tahun 2010 tentang Peraturan Disiplin Pegawai Negeri Sipil

Pasal 4 PP No. 53 Tahun 2010 Mengatur Larangan bagi setiap PNS

Polloma, M.M. (2002). Sosiologi Kontemporer. Jakarta: CV. Rajawali.

Ritzer. G. (2012). Teori Sosiologi dari Sosiologi Klasik sampai Perkembangan Terakhir Postmodern, Terjemahan Pasaribu. Yogyakarta: Pustaka Pelajar.

Santoso, T. \& Zulfa, E.A. (2008). Kriminologi. Jakarta: PT Raja Grafindo Persada.

Setiadi, E.M. \& Kolip, U. (2010). Pengantar Sosiolog, Pemahaman Fakta Dan Gejala Permasalahan Sosial: Teori, Aplikasi, Dan Pemecahannya. Jakarta: Prenatal Media Group.

Soekanto, S. (2002). Sosiologi Suatu Pengantar. Jakarta: PT Raja Grafindo Persada.

Sugiyono. (2008). Metode Penelitian Pendidikan Pendekatan Kuantitatif, Kualitatif, dan R\&D. Bandung: Alfabeta.

Sugiyono. (2014). Memahami Penelitian Kualitatif. Bandung: Alfabeta.

Sujarwa. (2011). IImu Sosial \& Budaya Dasar. Yogyakarta: Pustaka Pelajar.

Thoha, Miftah. (2003). Perilaku Organisasi Konsep Dasar dan Aplikasinya. Jakarta: Grafindo Persada

UU Nomor 20 Tahun 2001 tentang Perubahan UU Nomor 31 Tahun 1999 tentang Pemberantasan Tindak Pidana Korupsi

Walgito, B. (2004). Pengantar Psikologi Umum. Yogyakarta: Andi 
